\title{
Research on Control Strategy in Photovoltaic-Battery-Diesel Hybrid Micro-Grid
}

\author{
Yuanzhuo $\mathrm{Du}^{1}$ and Jinsong $\mathrm{Liu}^{2}$ \\ ${ }^{1}$ Shenyang Institute of Engineering, Shenyang, China \\ ${ }^{2}$ Electric Power Research Institute, State Grid Liaoning Electric Power Supply \\ Co. Ltd., Shenyang China \\ * Corresponding author: liu.jinsong@163.com
}

\begin{abstract}
It is facing resource shortage and environmental pollution around the globe, until the emergence of new renewable energy technology has reinvigorated traditional techniques. Development of renewable energy generation in China needs the joint efforts of all social sectors from policy to technique. Distributed generation combining with battery applied in micro-grid relieves a problem of resource shortage, and ensures load operation when power grid fault urgently. In this paper, photovoltaic is described briefly first. Then photovoltaic-battery-diesel micro-grid is established according to the situation about geographical environment, what is more workflow of the system is analyzed. Control strategy is shown according to condition of micro-grid. At last, micro-grid containing distributed generation established in Liaoning Province is quantitative illustrated in economic benefit. Distributed generation is added into micro-grid enhance the reliability of micro-grid even power grid. That makes a contribution to resource and environmental problem.
\end{abstract}

Keywords: photovoltaic-battery-diesel micro-grid, distributed generation, running mode of micro-grid

\section{Introduction}

With the increasing acute global energy crisis and environmental problem getting worse, renewable generation technology was born at the right time. DG (distributed generation) technology based on renewable energy is developing rapidly. DG combining with battery becomes a hot project about researching micro-grid in current. DG with small size locating on the user side is that using distributed resource to be multiple power generation equipment which comprehensive and gradient use of resource by 10 (35) kV and lower voltage grade accessed renewable energy. Renewable energy mainly include solar energy, wind, gas, biomass energy and so on. Developing key point of distributed generation is wind generation and PV (photovoltaic) in China. At present, with progressing of battery, distributed resource combining with battery was used widely. Due to adding DG with large size to grid, grid-connected is facing a big challenge to reconciling contradictory between DG and grid, releasing impact of DG to grid, therefore, concept of micro-grid is proposed. Micro-grid is a type of independent controllable system consisting of DG, battery, converters, load, monitor and protector. At the same time, micro-grid supply power and heat, and run with grid-connected or independent [1]. Combining DG and battery technology applied in independent micro-grid which can solve power supply in remote area and improve reliability of power supply. That is a good way to promote energy saving and emission reduction, and reduce the loss as well.

Currently, research on micro-grid technology is in the infancy with great gap between Occident and China. Many countries have established project model about micro-grid. Greece has established independent micro-grid of wind-PV-diesel-battery in Kythnos. 
There are many micro-grid pilot project in China, micro-grid pilot project in Yudaokou Village, Weichang County; Chengde City, Hebei Province is one of them. Zhejiang Power Grid establishing an independent micro-grid system in the south island of the East China Sea is the first power supply containing DG in China, which guide to DG independent micro-grid. Nowadays, PV output power stability, which lead the development of power grid. As we all know, solar resource is rather abundance in Liaoning Province where PV is generalized gradually in large and medium-sized city.

This paper has been given a kind of independent micro-grid containing DG based on resource superiority in Liaoning Province. This paper shows characteristic of independent micro-grid first. Then the paper analyzes power electronic device of independent microgrid applying DG and introduces technology about micro-grid. It analyzes PV-batterydiesel system that is established according to the situation of geographical environment. And micro-grid control is analyzed. Finally, economic benefit and value of PV-batterydiesel is illustrated in Liaoning Province.

\section{Preliminaries}

\subsection{Characteristic of Micro-Grid Containing DG}

Micro-grid consisting of DG, battery, load, monitor and protector is power supply with small size. The characteristic is as follow.

(1) Micro-grid has integrated multiple resource input and conversion unit.

(2) Using power electronic device makes micro-grid containing DG to be an organic unity.

(3) There is a PPC (Point of Common Coupling), therefore, micro-grid can be seen as a controlled generation or load. Micro-grid can output power when power is full in microgrid or power is not enough in power grid.

(4) Micro-grid can be connected operation or operation independently. The two smooth handoff can be realized.

(5) Micro-grid has its own upper controller which is optimal allocated to DG.

There are a large number of renewable resources which is intermittent in micro-grid, considering the reliability of micro-grid power supply containing DG. Multiple modes of protection are taken in control level.

\subsection{Basic Composition of PV}

2.2.1. Summary of PV: Solar module is key of PV system, which transfers solar energy into power. DC (Directional Current) is generated by PV system supplying to DC-load, or supplying to AC load if DC transfer AC by inverter. Power generated by PV can be used at any time in theory or stored and release in time by battery [2]. Structure of PV system is shown in Figure 1.

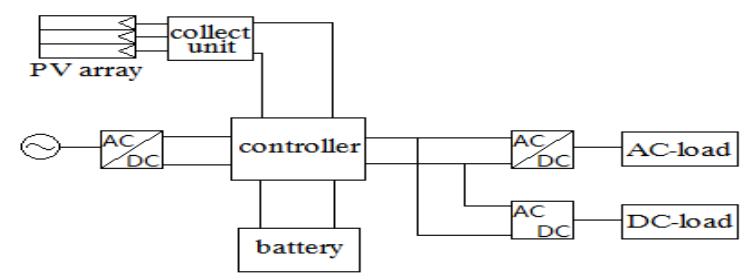

Figure 1. Structure of PV System 
Solar collector collect optical signal transmitting DC to solar controller to coordinating interaction among solar cell, battery and load. DC can be charged into battery by controller through bus unit from solar cell directly. Then DC-load can be supplied directly, AC-load can be supplied via inverter as well.

2.2.2. Solar cell: Solar cell is key device of PV system. Solar cell based on semiconductor material is a device that transfers solar energy into power directly. Solar cell is a large area p-n junction diode actually. Solar cell as an external power will work in positive condition. Grid will supply forward bias or reverse bias voltage to solar cell if solar cell combines with other power supply [3].

Solar cell can be seen as a device that generates stable photocurrent. The photocurrent is:

$$
I_{L}=A_{C}\left(C_{0}+C_{1} T\right) G
$$

Where, $A_{C}$ is effective area of solar cell. $C_{0}$ and $C_{l}$ are constant depending on material of photocell. $T$ is temperature of solar cell. $G$ is light intensity.

Considering physical truth that surface recombination and depletion zone of solar cell leakage, current of solar cell is:

$$
I=I_{L}-I_{S}\left\{\exp \left[\frac{q\left(U+I R_{S}\right)}{n k T}\right]-1\right\}-\frac{U+I R_{S}}{R_{s h}}
$$

In which, $R_{S}$ and $R_{s h}$ are equivalent series/parallel resistant in surface recombination and depletion zone respectively. $I_{S}$ is diode saturation current. $q$ is electron charge. $n$ is ideal factor of diode. $k$ is boltzmann constant. $T$ is thermodynamic temperature. $U$ is voltage of load.

Photoelectric characteristic curve of solar cell is shown in Figure 2.

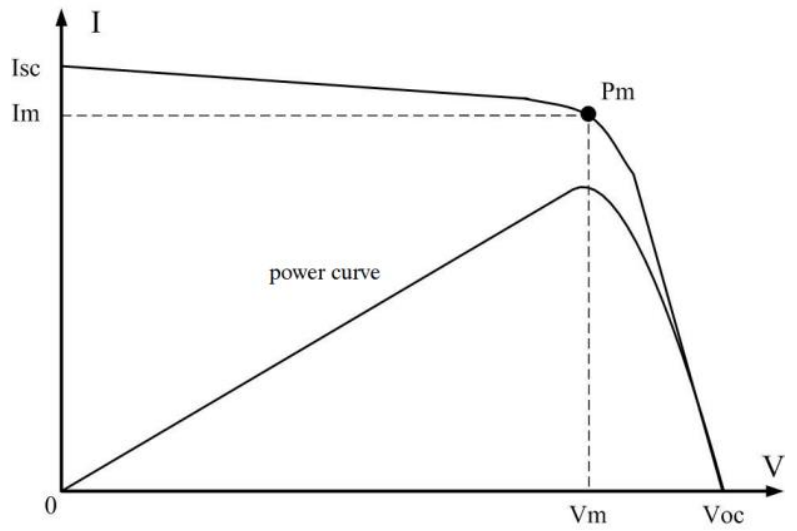

Figure 2. Photoelectric Characteristic Curve of Solar Cell

$P_{m}$ is MPP, the maximum output power is:

$$
P_{m}=I_{m} V_{m}
$$

Regarding efficiency of MPP as efficiency of solar cell usually:

$$
\eta=\frac{P_{m}}{S}
$$

Where, $\mathrm{S}$ is the ration of area projected on solar cell and incident light power.

Photocell curve caused by light effect is shown in Figure 3. 


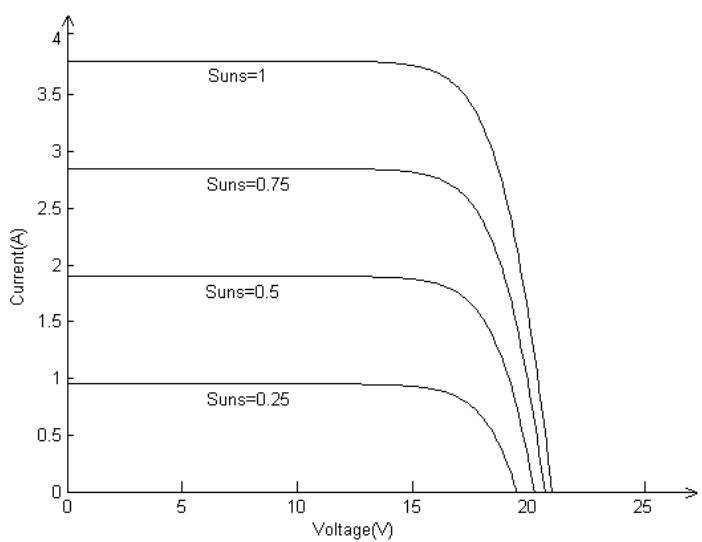

\section{Figure 3. Photocell Curve Caused By Light Effect}

As is shown in Figure 3, in the same temperature, short-circuit current of photocell is affected large by light intensity. The higher light intensity is, the higher short-circuit current is. The lower light intensity is, the lower short-circuit current is. With the increase of light intensity, short-circuit current of photocell is increasing, open-circuit voltage is going up slightly, and power of photocell is increasing too.

Photocell curve affected by temperature is shown in Figure 4.

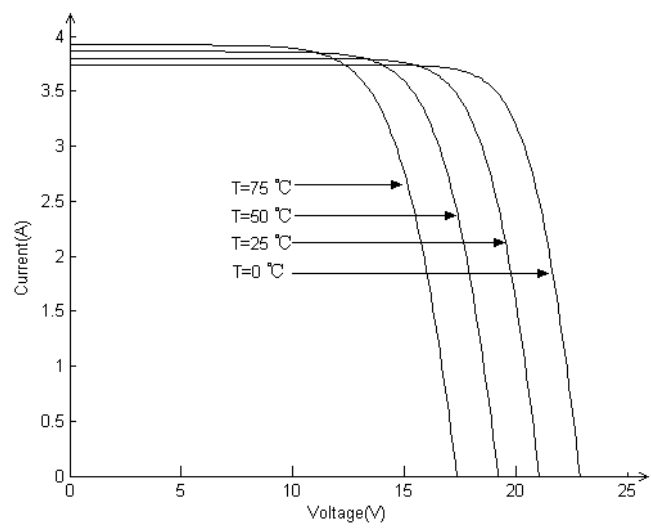

\section{Figure 4. Photocell Curve Affected By Temperature}

As is shown in Figure 4, if temperature is a constant, open-circuit voltage of photocell will be affected large by temperature. The lower the temperature is, the higher opencircuit voltage is. The higher the temperature is, the lower open-circuit voltage is. With increasing of temperature, short-circuit of photocell rise slightly, and open-circuit voltage is lower. That is to say, power of solar cell is going down with the increase of temperature.

Therefore, light intensity and temperature is the factor that should be considered to solar cell effect.

\subsection{Battery System}

In PV system, solar cell component transfer solar energy to DC. Then DC transfer power to chemical energy stored by battery, in order to supplying stable power in real time. Due to intermittent and random feature of solar energy, battery becomes belt between power supply and load [4]. Structure of battery system is shown in Figure 5. 


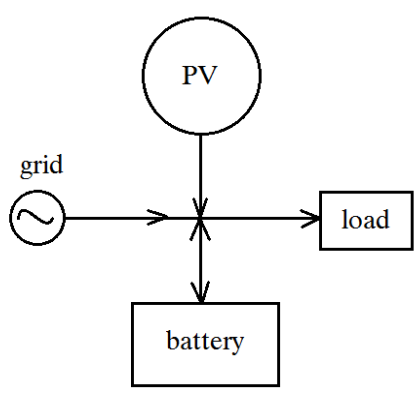

\section{Figure 5. Structure of Battery System}

Power output by solar cell is in proportion to solar irradiance projecting on the surface of solar cell. PV has great randomness and intermittent due to different solar irradiance, power output by solar cell change with the weather. Therefore, there are 3 working modes when PV works:

(1) Charge battery by PV when there is enough power generated by solar cell without load.

(2) PV supply power to load via inverter first, and charge battery second, when there is enough power generated by solar cell with load.

(3) Power supplied to load by PV based on inverter, when there is not enough power generated by solar cell with load. Grid replenishes power combining with PV to load.

When PV does not work, battery needs depth of discharge supplying to load. Once battery with insufficient power, power might be supplied by grid

\section{Basic Principle of Micro-Grid}

\subsection{Basic Structure of Micro-Grid}

DG works when micro-grid with alone operation. PV-battery-diesel micro-grid consists of PV unit, storage unit and diesel generator unit. Micro-grid can work off grid, that is micro-grid can work alone with DG [5-6]. Structure of micro-grid is shown in Figure 6.

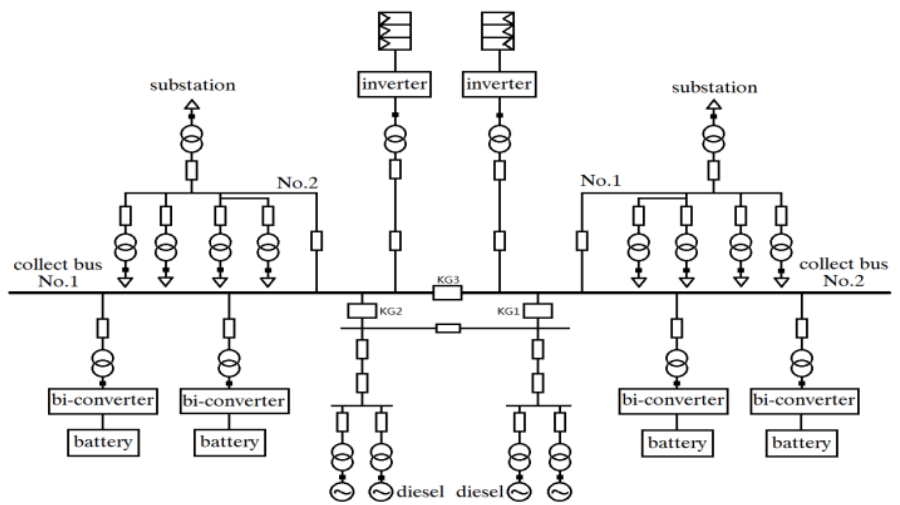

Figure 6. Structure of Micro-Grid

3.1.1. PV unit: Solar energy can be transferred to power by PV unit, which is composed of PV array, junction box, inverter, etc. AC transferred from solar energy is collected by PV component via inverter to load. PV system can work parallel with grid and work alone as well. It will work with grid connected inverter, if PV system works parallel with grid; otherwise, it needs to work with battery [7-9]. 


\section{Grid connected inverter}

Grid connected inverter is key of grid connected system. Grid connected inverter transfer DC from PV array to AC, working with grid together. Three-phase full bridge inverter circuit topology is shown in Figure 7.

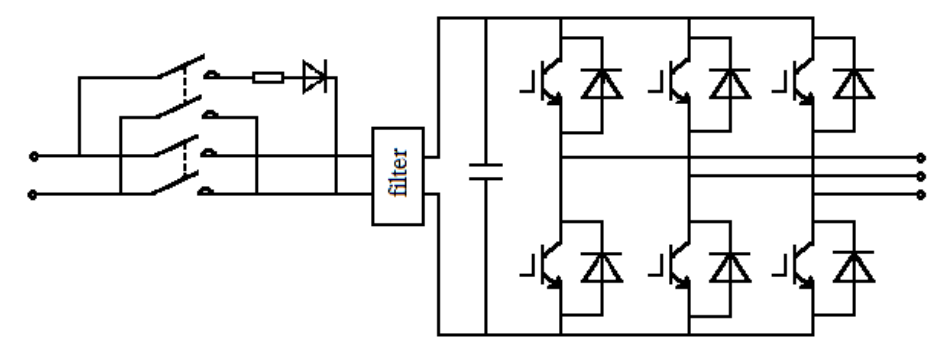

Figure 7. Three-Phase Full Bridge Inverter Circuit Topology

DC from solar cell through booster circuit rise voltage to the DV (directional voltage) of inverter needed. Inverter bridge circuit DV after booster circuit converse to AV (alternating voltage) is commonly used. Anti reverse of DC side is to avoid power flow from grid to PV array. Filter is to restrain harmonic flowing to grid, in order to reducing the influence of grid. When there is any external fault in inverter, closing down the contactor to make protection and isolation of inverter come true.

\section{Independent PV system}

Independent PV system is to consuming PV power in internal closed circuit without connecting with grid. Namely micro-grid containing DG works alone when there is any fault in grid. Independent PV system needs to work with battery. Controller is key of power distribution, in order to managing charge and discharge of battery.

3.1.2. Storage Unit: Storage unit is to supplying power to load via PV or grid in real time consisting of battery, bi-converter, charge and discharge controller, etc. Charge and discharge controller can manage battery effectively. That is composed of collecting circuit, protecting circuit, DC/DC main circuit and driving circuit. PV array charges battery alone, until reaching a certain value when battery power is insufficient. During charging, charge and discharge controller collect voltage of battery constantly and stop to charge battery till reaching a certain value.

When battery is overflow and light is strong enough, PV array stop to charge battery but start to afford load. When light is weak and load is increasing, PV array and battery supply power to load together. Bi-converter applying in storage is an important means about renewable resource, which is applicable to dynamic storage. Namely power from battery supply to load when grid is fault or solar power is insufficient. Charging battery when power is sufficient, battery makes the lash-up effect in independent micro-grid.

3.1.3. Maximum Power Point Tracking Control: Under a certain light intensity and temperature, the maximum power of PV array is output when PV array output a certain voltage. The point of PV array arriving at the top of power curve is named MPP (Maximum Power Point). Adjusting work point of PV array according to external factors is to making the point become MPP. The technology is named MPPT (Maximum Power Point Tracking) which makes battery get most [10].

At the same temperature, the stronger light intensity shining to PV array is, the higher power is, otherwise, power is lower. In the same light conditions, the higher temperature of photocell is, the lower output power is, otherwise, the power is higher. Incremental 
conductance method is a better way. According to output characteristic of PV array, MPP is:

$$
d P=d U=0
$$

Where, $P$ is output power of PV array. $U$ is output voltage.

For photocell, there is:

$$
\begin{aligned}
& P=U I \\
& \frac{d P}{d U}=I+U \frac{d I}{d U}=0 \\
& \frac{d I}{d U}=-\frac{I}{U} \\
& \frac{I}{U}+\frac{d I}{d U}
\end{aligned}
$$

Therefore, judging the symbol of formula (9), MPPT is known. When the symbol is positive, this point is on the left of MPP, output voltage should be decrease. When the symbol is negative, this point is on the left of MPP, output voltage should be increase. When the magnitude is 0 , this point is right MPP. Flow chart of incremental conductance is shown in Figure 8.

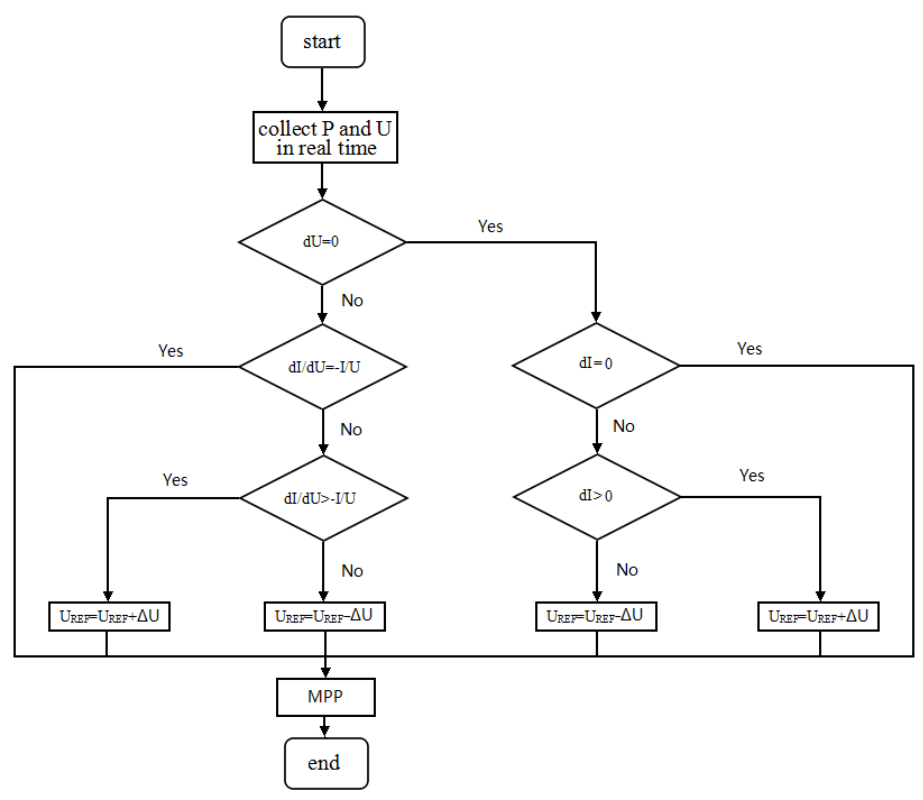

Figure 8. Flow Chart of Incremental Conductance

\subsection{Working Process of Micro-Grid}

1. Normal operation of grid

Power from PV array supply to battery first, until reaching a certain value, power from PV array is sent to collect bus via collector. Supplying solar energy to load No.1 and load No.2 first, which makes sure output is maximum and getting most. Grid supply power to load when solar energy is insufficient, when solar energy is sufficient, supplying power to both micro-grid No.1 and No.2 first, returning back to grid and flowing to low level 
second, diesel generator stops when power is enough. Namely disconnect KG1 and KG2, close KG3.

\section{Grid is fault}

When there is fault, system switch to independent micro-grid operation automatically. PV energy supply to substation No.1 and No.2, excess energy flow to battery. When PV energy is insufficient, battery works with depth of discharge to meet the demand of power quality. When PV energy and battery are both insufficient to afford load, using diesel generator, closing KG1 and KG2, load No.1 and No.2 are supplied together among diesel generator, storage system and PV system. Closing KG1 and KG3, diesel generator, storage system and PV system in No.1 side supply power together to load No.1 and No.2. Closing KG2 and KG3, diesel generator afford load No.1 and No.2 respectively with PV system and storage system until trouble removal.

\section{Resumption of power supply}

After removing trouble, system adjust voltage phase of inverter automatically. Voltage frequency, phase of micro-grid bus and of AC-bus are in allowed range. Micro-grid operation transferred from independent mode to parallel mode [11].

\section{Control Strategy}

\subsection{Operation Mode}

Micro-grid contains a variety of DG. Control mode need to collect information of control switch in real time to real-time switch. When working connected with grid, DC/AC of PV-battery system keep DV constant, DC/DC of battery control output power according to charging current, in order to remaining output power of photocell is smaller than charging power [12-19].

When there is any fault in grid, DG in micro-grid detects that bus voltage or frequency is over range, PV-battery system works into standby situation. Controller of micro-grid mode detects that loop switch of micro-grid close first. Enter independent state second. When external voltage is normal, loop switch disconnect, PV-battery system stop to independent operation, working connected with grid again. Operation mode of system is shown in Figure 9.

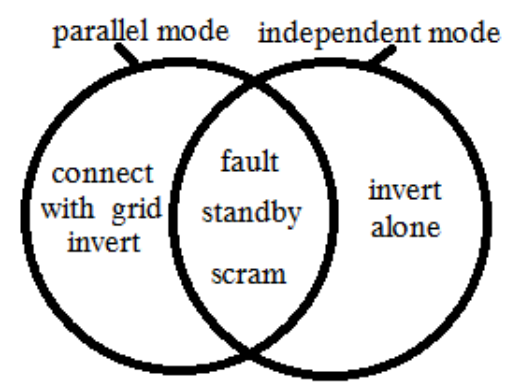

Figure 9. Operation Mode of System

When micro-grid works alone, KG1, KG2 and KG3 close or disconnect according to different conditions. When KG1, KG2 and KG3 are all disconnect, micro-grid No.1 and No. 2 work independently with PV-battery system. When KG3 disconnect with KG1 and KG2 close, micro-grid No.1 and No.2 work respectively with PV-battery-diesel system, otherwise work alone. When KG3 close, micro-grid No.1 and No.2 work together parallel. The condition is in PV-battery mode with whole grid. Operation method of micro-grid is shown in Tab. 1. 
Table 1. Operation Method of Micro-Grid

\begin{tabular}{|c|c|c|c|c|}
\hline $\begin{array}{c}\mathrm{K} \\
\mathrm{G} 1\end{array}$ & $\begin{array}{l}\mathrm{K} \\
\mathrm{G} 2\end{array}$ & K3 & Operation method & Operation mode \\
\hline- & - & - & $\begin{array}{l}\text { Small grid No.1 works alone } \\
\text { Small grid No.2 works alone }\end{array}$ & $\begin{array}{l}\text { Small grid with } \\
\text { PV-battery mode. } \\
\text { Battery is main } \\
\text { power. }\end{array}$ \\
\hline+ & - & - & $\begin{array}{l}\text { Small grid No.1 with PV-battery-diesel works } \\
\text { Small grid No. } 2 \text { works alone }\end{array}$ & \multirow{2}{*}{$\begin{array}{l}\text { Small grid with } \\
\text { PV-battery-diesel } \\
\text { mode. Diesel } \\
\text { generator is main } \\
\text { power. }\end{array}$} \\
\hline- & + & - & $\begin{array}{c}\text { Small grid No.1 works alone } \\
\text { Small grid No.2 with PV-battery-diesel works }\end{array}$ & \\
\hline+ & + & - & $\begin{array}{l}\text { No.1 and No. } 2 \text { work respectively, whole grid with } \\
\text { PV-battery-diesel work }\end{array}$ & \multirow{4}{*}{$\begin{array}{l}\text { Whole grid with } \\
\text { PV-battery-diesel } \\
\text { mode. Diesel } \\
\text { generator is main } \\
\text { power. }\end{array}$} \\
\hline- & + & + & $\begin{array}{l}\text { No.1 and No. } 2 \text { work parallel, whole grid with PV- } \\
\text { battery-diesel work }\end{array}$ & \\
\hline+ & + & + & $\begin{array}{l}\text { No.1 and No. } 2 \text { work parallel, whole grid with PV- } \\
\text { battery-diesel work }\end{array}$ & \\
\hline+ & - & + & $\begin{array}{l}\text { No.1 and No. } 2 \text { work parallel, whole grid with PV- } \\
\text { battery-diesel work }\end{array}$ & \\
\hline- & - & + & $\begin{array}{l}\text { No.1 and No. } 2 \text { work parallel, whole grid with PV- } \\
\text { battery work }\end{array}$ & $\begin{array}{l}\text { Whole grid with } \\
\text { PV-battery mode. } \\
\text { Battery is main } \\
\text { power. }\end{array}$ \\
\hline
\end{tabular}

In this table, - means disconnect, + means close

Operation mode control depending on switching of mode control collect information of grid or micro-grid in real time with smooth way to switch operation mode flexibly, there are three operation methods. In whole grid of PV-battery mode and PV-battery-diesel mode as an example, switching strategy flow chart is shown in Figure 10.
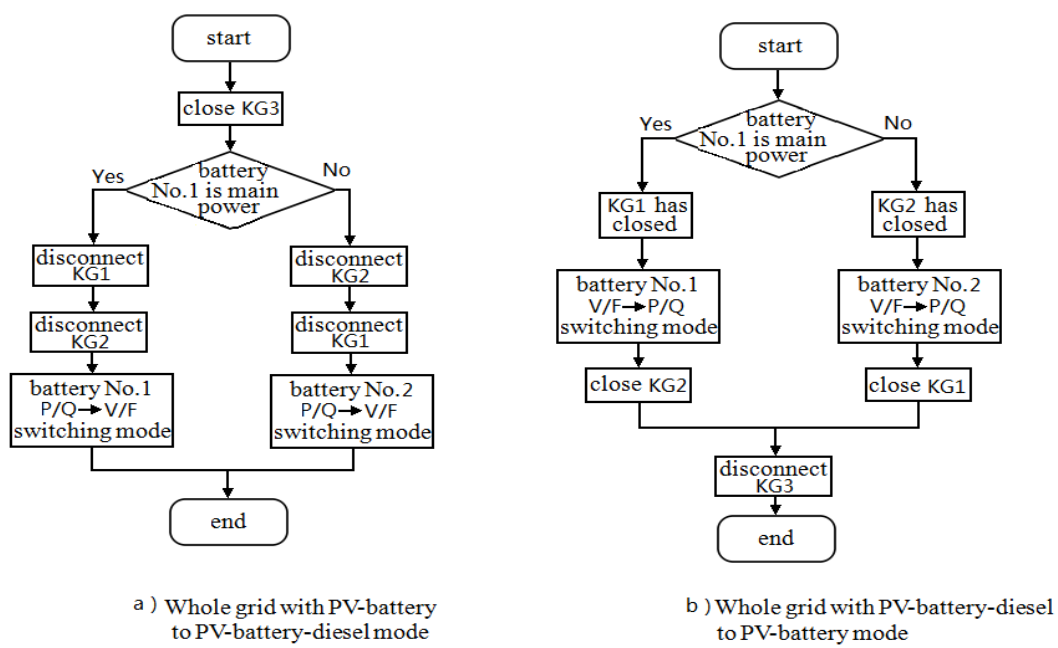

Figure 10. Switching Strategy Flow Chart

\subsection{Transient Stability Control}

When micro-grid works alone, the anti disturbance ability of fault is weak. It is necessary to locate and isolate quickly for fault in micro-grid. Therefore, collecting realtime information and operating quickly to keeping grid safe is necessary, otherwise, micro-grid with failing to afford load and loosing stability will break down. For the PVbattery-diesel micro-grid that is protected by double ways with centralization, 6 series of 
bus differential protection and a set of line protection are employed. Answering fault ability is increased to keeping grid safe [20]. Range of transient stability control and protection is shown in Figure 11.

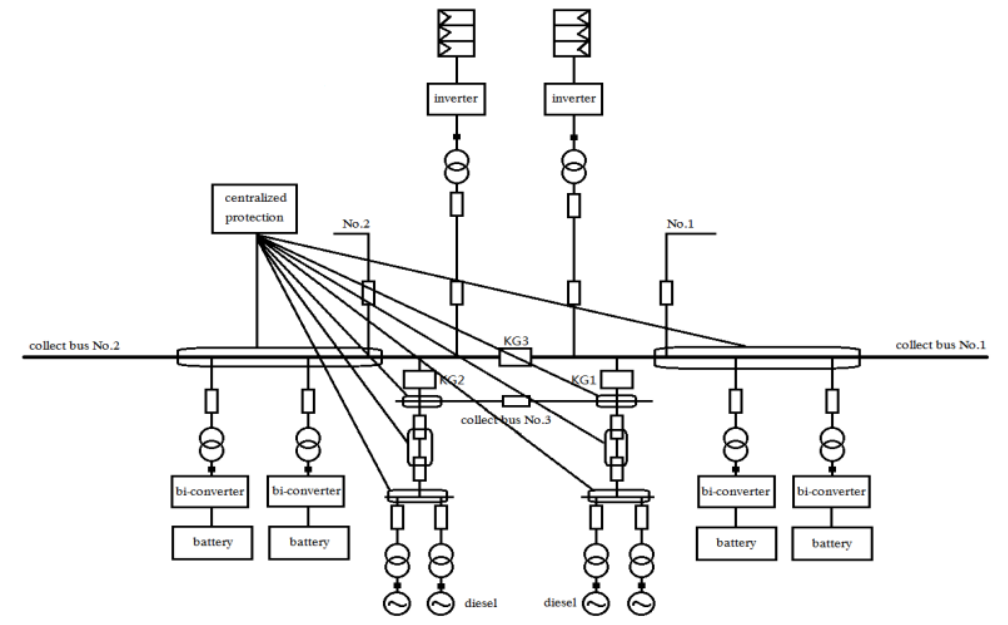

Figure 11. Range Of Transient Stability Control and Protection

\subsection{Distribution Protection Control}

Due to accessing DG, flows direction of distribution network change from one-way to two-way. Therefore, micro-grid must be allocated perfect protection for keeping safe in different conditions. Employing PCS mainly, and AC protection, AC over/under voltage protection and over temperature protection managed by centralization, differential protection locate fault quickly and accurately. Adopting passive optical network to achieving collection of grid data, when system detect over current, over voltage or over temperature, blocking pulse, cutting off breaker, stopping and warning at once. AC protection sets timing and limiting current protection mainly. When AC over/under voltage protection detect there is abnormal, cutting off contactor according to the setting value before and stopping to transmitting power or charging battery. Over temperature protection, protect hardware temperature. Beyond that, digital temperature protection is provided. Once the temperature is too high, it might turn into standby until temperature recovery with clearing sign automatically. Range of distribution protection is shown in Figure 12.

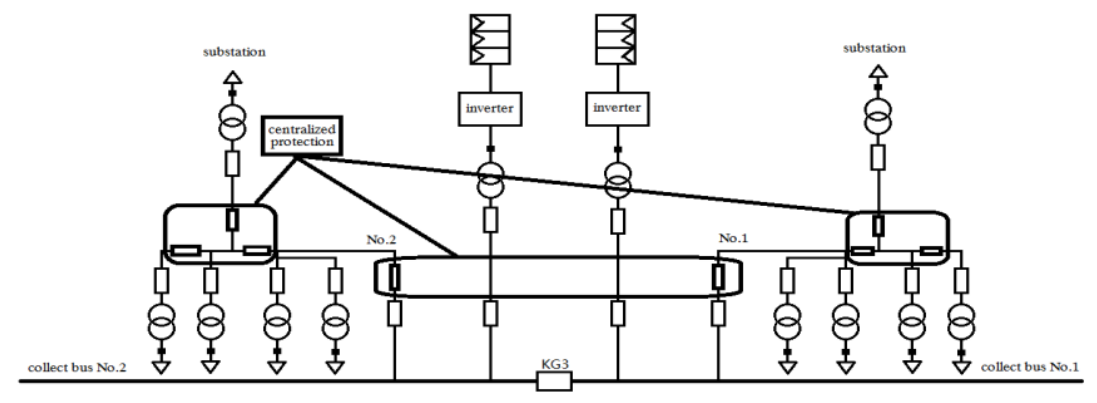

Figure 12. Range Of Distribution Protection

\subsection{Grading Operation of Micro-Grid}

When micro-grid works alone, affording load by PV-battery-diesel system [21]. When power is enough, micro-grid works without grading operation. When power can afford a certain amount of load, abandoning load in lower level first, affording main load only, 
when power is earning of many, returning back to grid and afford another load in next level.

\section{Economic Benefit of Micro-Grid}

Establishing PV-battery-diesel micro-grid according to geographical features of Liaoning Province, liaoning Province is a place with medium type of solar energy in China. Total solar radiation a year is $1,389-1,625 \mathrm{~kW} \cdot \mathrm{h} / \mathrm{m}^{2}$. Land area of Liaoning Province is $149,500 \mathrm{~km}^{2}$. Assumption using $0.06 \%$ of land to building PV array with right angle, if average conversion rate of PV panel in unit area is $9 \%$, optical radiation a year in all is $1,507 \mathrm{~kW} \cdot \mathrm{h} / \mathrm{m}^{2}$ and utilization rate is $0.367 \%$. Then, average production of $\mathrm{PV}$ panels a year is $4,753.67 \mathrm{~kW} \cdot \mathrm{h}$. Commercial power price is $1 \mathrm{yuan} / \mathrm{kW} \cdot \mathrm{h}$, saving $4,753.63$ yuan a year. After 25 years, 118,840yuan can be saved in all.

\section{Conclusion}

Generated by renewable energy is more and more becoming centralized access and distributed access simultaneously in China. Combining DG and storage technology according to geographical features, DG works parallel with grid and switching to work alone automatically, when grid is in trouble. When micro-grid works alone, employing many kinds of energy to keeping supply power in real time. Double protection and smooth switching in varieties of modes, in order to ensure power supply and quality, economic benefit is pointed out in this paper. Applying PV-battery-diesel can improve reliability of power supply. Application of renewable resource promotes energy saving and emission reduction to a certain extend.

\section{Acknowledgements}

This paper can not be completed without help of several people. Yan Zhao, Tieyan Zhang, especially Shipeng Du. To all of them, I wish to express my sincere gratitude.

\section{References}

[1] C. S. Wang and P. Li, “Automation of Electric Power Systems”, vol. 24, (2010), pp. 10.

[2] L. Zhang, K. Sun and T. J. Wu, "Transactions of China Electrotechnical Society”, vol. 28, (2013), pp. 248.

[3] H. Lin, X. Li and Y. Z. Liu, "Rare Metal Materials and Engineering", vol. 38, (2009), pp. 722.

[4] Y. Zhang, Q. Li and C. H. Li, "Power System Protection and Control", vol. 38, (2010), pp. 212.

[5] S. Y. Wang, "Electric Power Automation Equipment", vol. 32, (2012), pp. 5.

[6] B. Zhao, X. S. Zhang and P. Li, "Automation of Electric Power Systems", vol. 37, (2013), pp. 161.

[7] Z. Zeng, H. Yang and R. X. Zhao, "Electric Power Automation Equipment, vol. 32, (2012), pp. 5.

[8] Z. Zeng, H. Yang and R. X. Zhao, "Automation of Electric Power Systems", vol. 36, (2012), pp. 28.

[9] X. Chen, Z. Wei and X. F. Hu, "Transactions of China Electrotechnical Society, vol. 29, (2014), pp. 71.

[10] L. Zhou, J. Wu, Q. H. Li. High Voltage Engineering, 34, 1145 (2008)

[11] X. Y. Zhang, J. Shu and C. H. Wu, "Power System Protection and Control", vol. 1, (2014), pp. 55.

[12] F. Tang and X. Zhou, "Automation of Electric Power Systems, vol. 1, (2014), pp. 15.

[13] S. H. Xu and J. L. Li, "Proceedings of the CSEE", vol. 1, (2013), pp. 25.

[14] Y. Bi, J. F. Wu and M. Ding, "Automation of Electric Power Systems", vol. 1, (2014), pp. 73.

[15] X. Chen, Q. H. Ji and F. Liu, "Transactions of China Electrotechnical Society", vol. 1, (2014), pp. 163.

[16] M. D. Xue, B. Zhao and X. S. Zhang, "Automation of Electric Power Systems", vol. 1, (2014), pp. 1.

[17] B. Li, H. L. Bao and L. Guo, "Electric Power Automation Equipment", vol. 34, (2014), pp. 8.

[18] M. X. Liu, L. Guo and C. S. Wang, "Automation of Electric Power Systems", vol. 36, (2012), pp. 19.

[19] J. Xiao, Z. Q. Zhang and P. Zhang, "Automation of Electric Power Systems”, vol. 1, (2014), pp. 19.

[20] P. Li, C. S. Wang and B. B. Huang, "Electric Power Automation Equipment, vol. 33, (2013), pp. 35.

[21] N. C. Zhou, M. Jin and Q. G. Wang, "Automation of Electric Power Systems", vol. 37, (2013), pp. 13. 


\section{Authors}

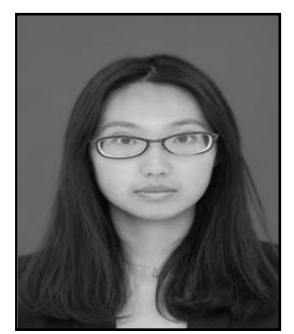

Yuanzhuo Du, received the B.E. degree in School of Mechatronics Engineering from Shenyang Aerospace University, Liaoning, China in 2013. She is currently working towards the Master in Electrical Engineering in Shenyang Institute of Engineering.

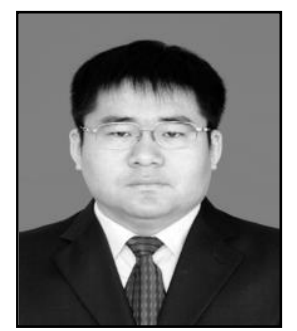

Jinsong Liu, received his Master degree in Electrical Engineering from Harbin Institute of Technology in 2005. He is currently the director of Technology Department in State Grid Liaoning Electric Power Research Institute. His professional and technical fields include calculation of power system simulation and research of intelligent power grid. 